\title{
Felsőfokú óvodapedagógus- és tanítóképzés a Babeș-Bolyai Tudományegyetemen
}

\author{
Szabó-Thalmeiner Noémi \\ Babeș-Bolyai Tudományegyetem Szatmárnémeti Kihelyezett Tagozat
}

\begin{abstract}
Jelen tanulmányban egy többfázisú kutatás eredményeit mutatjuk be, melyet a Babeș-Bolyai Tudományegyetem Pszichológia és Neveléstudományok karán végeztünk az óvodapedagógusés tanitóképzös hallgatók körében. Az eredmények helyes keretben való értelmezése érdekében a tanulmány elsö részében a tizenhat éve beindult állami magyar felsőfokú óvodapedagógusés tanitóképzés törvényi szabályozását, megszervezését taglaljuk kitérve a változások tantervre gyakorolt hatásának a bemutatására is. Kutatásunkkal arra kerestünk választ, hogy miként látják, hogyan itélik meg a végzős hallgatók az intézményünkben zajló képzés színvonalát, felkészültségük mértékét a pedagógusi pályára.
\end{abstract}

Kulcsszavak: óvóképzés, tanitóképzés, határon túli magyarok oktatása, harmadfokú képzés

\section{Intézményi, jogi keretek, képzési formák}

A Babeș-Bolyai Tudományegyetem Pszichológia és Neveléstudományok Kara 1999-ben elsőként vállalta fel Romániában a felsőfokú, állami, magyar tannyelvü tanítóképzés majd óvodapedagógus képzés beindítását, működtetését, a 84/1995-ös oktatási törvény alapján², mely lehetővé tette, hogy az addig középiskolai szinten, pedagógiai líceumokban, illetve ideiglenesen érettségi utáni, posztliceális ${ }^{3}$ formában megvalósuló óvodapedagógus- és

1 Jelen tanulmány az alábbi kötetben jelent meg: Pusztai Gabriella és Márkus Zsuzsanna (2017, szerk.): Szülöföldön magyarul. Iskolák és diákok a határon túl. Debreceni Egyetemi Kiadó, Debrecen, 298-311.

2 Ezt a lehetőséget a magánegyetemek korábban felismerték, korábban léptek, ebben az időben már a nagyváradi Sulyok István Református Főiskolán (későbbi Partiumi Egyetem) illetve Marosvásárhelyen, a Károli Gáspár Református Egyetem Tanítóképző Főiskolai Karának kihelyezett tagozatán is működik felsőfokú tanítóképzés. A BBTE-n kívül állami magyar tannyelvú tanítóképzést a 2001/2002-es tanévben indít be a Nagyváradi Állami Egyetem, majd 2012-ben megszünteti, teret engedve a Partiumi Egyetemnek a képzés megvalósítására. Az egyezmény azonban csak egy évig tart, a 2013/2014-es tanévtől, az Állami Egyetem újra beindítja a tanítóképzést az intézmény keretein belül. (Szabó-Thalmeiner, 2013)

3 A poszliceális képzés beindítására 1990 után a nagy tanítóhiány miatt volt szükség, ekkor több pedagógiai tanítóképzés főiskolai szinten valósulhasson meg, szakpárosításban: a tanítóképzést idegen nyelv oktatói, rajz, ének és testnevelés szakkal lehetett párosítani. Ennek figyelembevételével az 1999/2000-es tanévre az egyetem négy helyszínen, Székelyudvarhelyen, Kézdivásárhelyen, Kolozsváron és Szatmárnémetiben tanítóképző - angol nyelv oktatói, egy helyszínen, Nagyenyeden ${ }^{4}$ pedig tanítóképző - francia nyelv oktatói képzés beindítására szervez felvételit nappali tagozaton, majd a 2000/2001-es tanévtől Marosvásárhelyen is beindítja a képzést óvodapedagógustanítóképző szakpárosítással. Ettől az évtől kezdődően a Kar távoktatásos formában is beindítja a képzést kolozsvári központtal ${ }^{5}$ (Szabó-Thalmeiner, 2009, 2011b).

Románia Európai Unióhoz való csatlakozása ${ }^{6}$ változást idéz elő a felsőoktatásban is. A felkészülési időszakban a BBTE-n a Bolognai Nyilatkozathoz igazodva olyan átszervezése-

líceum beindítja ezt a három éves időtartamú, harmadfokú képzést.

${ }^{4}$ Az alacsony diáklétszám miatt Nagyenyeden mára már megszűnt a képzés.

5 A távoktatásos képzés három helyszínen: Székelyudvarhelyen, Kézdivásárhelyen és Szatmárnémetiben valósult meg, két éven keresztül.

6 2007. január 1-jén. 
ket foganatosítanak meg, melyek elősegítik a hallgatók mobilitását a képzési időszakban, illetve lehetővé teszik az oklevelek elismerését az európai uniós tagországokban7. Ennek következtében a 2005/2006-os tanévtől egyetemi szintűvé válik az óvodapedagógus- és tanítóképzés a BBTE-n, három éves képzési idővel BA szintű képzési formában képez tanárokat $A z$ óvoda és elemi iskolai oktatás pedagógiája szakon, előbb csak nappali képzés formájában, majd a 2006/2007-es tanévtől kezdődően távoktatásos formában is (SzabóThalmeiner, 2011a).

A bolognai rendszer lehetővé teszi a mesteri szinten történő szakosítást. Tanárok, tanítók és óvodapedagógusok számára a 2010/2011-es tanévben Székelyudvarhelyen és Szatmárnémetiben indult MA szintü képzés Hatékony kommunikációs és tanulási stratégiák a közoktatásban szakosítással, mely azonban rövid életű volt, a törvényi szabályozás változásai miatt, a következő tanévben nem indulhatott be újra a képzés. Jelenleg az Intézet keretén belül Kolozsváron működik mesteri képzés, mely az Alternativ módszerek az óvodában és az elemi oktatásban8 szakon nyújt továbbképzési lehetőséget a hallgatóknak.

Az 1/2011-es oktatási törvény elfogadása újabb változásokat hoz a pedagógusképzés terén. A törvény 236. cikkelye értelmében az óvodapedagógusok és tanítók képzése BA és MA szinten zajlik, majd egy év gyakorlati idővel zárul. E szabályozás értelmében a jövendőbeli óvodapedagógusok és tanítók hat évnyi felkészülési idő után válhatnának csak szakképzett pedagógusokká. A törvény módosítása azonban nem várat sokáig magára, az oktatásügyi miniszter 5745/13.09.2012-es rendelete alapján az óvodapedagógusok és ta-

\footnotetext{
7 A Bolognai Nyilatkozatot 1999 júniusában írta alá Európa több államának oktatási szakértője, köztük Andrei Marga, Románia akkori oktatási minisztere, később a BBTE rektora, akinek nagy szerepe volt a bolognai rendszer gyakorlati bevezetésében egyetemünkön. (Az európai felsőoktatási térség. Európa oktatási minisztereinek közös nyilatkozata 1999)

8 2013-tól működik.
}

nítók számára nem kötelező a didaktikai mesteri szak elvégzése.

Ugyancsak az 1/2011-es oktatási törvény rendelkezik a felsőoktatási intézmények megszervezéséről is (131-133. cikkelyek). Ennek értelmében az egyetemeken a karoknak alárendelt Intézetek alakulhatnak, melyek magukba foglalják egy vagy több képzési terület szakembereit (Stark, 2012). Kihasználva a lehetőséget a BBTE Pszichológia és Neveléstudományok Karán 2011-ben megalakul a Pedagógia és Alkalmazott Didaktika Intézet, mely egy szervezeti egységbe tömöríti a pedagógia, az óvodai és elemi iskolai oktatás pedagógiája szakot, a tanárképzést és -továbbképzést (1. 1. ábra).

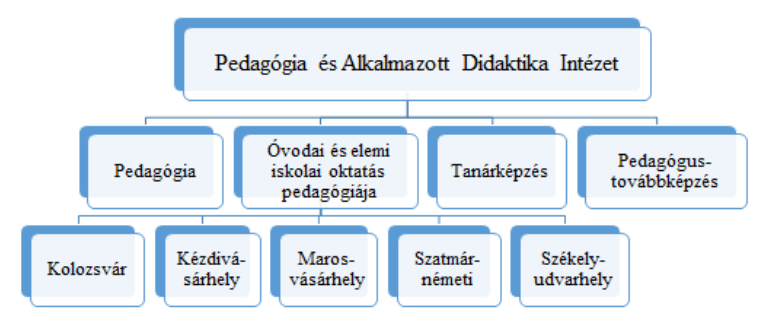

1. ábra: A 2011-ben alakult Pedagógia és Alkalmazott Didaktika Intézet szerkezete ${ }^{9}$

\section{Szakosítások, tantervi változások}

Amint az előző, felvezető fejezetből kiderült, tizenhat éves működése során a BBTE óvodapedagógus és tanítóképzésében számos változás ment végbe, mely kihatott a képesítésre s ezzel párhuzamosan a képzési tartalomra, a tantervre is.

A képesítés terén kezdetben nagy bizonytalanság figyelhető meg (1. 1. táblázat): első évben tanító - nyelvoktató képzést nyújt az egyetem, majd a következő tanévtől ezt kiegészítik az óvodapedagógusi képzéssel. Az első évfolyam államvizsgájakor azonban kiderül, hogy az itt szerzett nyelvoktatói képesítést nem tekintik egyenértékűnek a nyelvszakos oklevéllel, ezért

\footnotetext{
9 Az érdeklődés hiányában az Intézet jelenleg nem működteti a pedagógia szakot. A pedagógus-továbbképzés a kolozsvári központ mellett Székelyudvarhelyen és Szatmárnémetiben is működik, II. fokozati és I. fokozati vizsgákat szervez az óvodapedagógusok és tanítók számára.
} 
Felsőfokú óvodapedagógus- és tanítóképzés a Babeș-Bolyai Tudományegyetemen

2003-tól csak tanítói képesítést lehet szerezni a képzés során. Állandósul a helyzet a bolognai rendszer bevezetésével (2005-től), a végzősök tanári képesítést kapnak, mely feljogosítja őket arra, hogy az óvodában illetve az elemi oktatásban tanítsanak ${ }^{10}$.
A fentiekben bemutatott képesítések alakulása illetve az intézményi változások természetes módon kihatottak a tantervre is, tizenhat éves működése során az óvodapedagógus és tanítóképzés tanterve szinte évről évre változott, hol kisebb, hol nagyobb mértékben.

\begin{tabular}{|c|c|c|l|}
\hline Felvételi éve & Államvizsga éve & $\begin{array}{c}\text { Képzési } \\
\text { forma }\end{array}$ & \multicolumn{1}{|c|}{ Képesítés } \\
\hline 1999 & 2002 & nappali & tanító és idegennyelv-oktató (angol vagy francia nyelv) \\
\hline 2000 & 2003 & nappali & óvodapedagógus, tanító és idegennyelv-oktató \\
\cline { 2 - 4 } & 2004 & távoktatás & óvodapedagógus és tanító \\
\cline { 2 - 4 } & nappali & óvodapedagógus, tanító és idegennyelv-oktató \\
\hline 2001 & 2005 & nappali & tanító és idegennyelv-oktató (angol vagy francia nyelv) \\
\hline 2002 & 2006 & nappali & tanító \\
\hline 2003 & 2007 & nappali & tanító \\
\hline 2004 & 2008 & nappali & $\begin{array}{l}\text { tanár az elemi és óvodai oktatás számára (egyetemi szintű } \\
\text { képzés) }\end{array}$ \\
\hline $2006-2015$ & $2009-2018$ & $\begin{array}{c}\text { nappali és } \\
\text { távoktatás }\end{array}$ & $\begin{array}{l}\text { tanár az elemi és óvodai oktatás számára (egyetemi szintủ } \\
\text { képzés) }\end{array}$ \\
\hline
\end{tabular}

1. táblázat: A BBTE óvó- és tanítóképző főiskolái/tagozatai által biztosított képesítés ${ }^{11}$ (Szabó-Thalmeiner, 2013. 243. o.)

A jelentősebb tantervi változások a hármas illetve a Pedagógia és Alkalmazott Didaktika szakosítás bevezetésével (2000/2001), a csak Intézet (továbbiakban PADI) megalapításával tanítói szak beindításával (2004/2005) majd a érhető tetten. (1. 2. táblázat) bolognai rendszer bevezetésével (2005/2006)

\begin{tabular}{|l|c|c|c|c|c|}
\hline & $\mathbf{1 9 9 9 / 2 0 0 0}$ & $\mathbf{2 0 0 0 / 2 0 0 1}$ & $\mathbf{2 0 0 4 / 2 0 0 5}$ & $\mathbf{2 0 0 5 / 2 0 0 6}$ & $\mathbf{2 0 1 2 / 2 0 1 3}$ \\
\hline Ped.-pszich. elmélet & $19,5 \%$ & $18,9 \%$ & $31,2 \%$ & $45,8 \%$ & $42,4 \%$ \\
\hline Pedagógiai gyakorlat & $13,5 \%$ & $18,2 \%$ & $19 \%$ & $19,5 \%$ & $11,32 \%$ \\
\hline Tantárgy-pedagógiák & $14,6 \%$ & $10,5 \%$ & $16,9 \%$ & $18 \%$ & $19 \%$ \\
\hline $\begin{array}{l}\text { Általános múveltségi } \\
\text { tárgyak }\end{array}$ & $27,9 \%$ & $27,1 \%$ & $32,9 \%$ & $16,7 \%$ & $27,24 \%$ \\
\hline Idegen nyelvi képzés & $24,5 \%$ & $25,3 \%$ & & & 2136 \\
\hline Összesen - óraszám & 2213 & 2083 & 2087 & 2016 & 2 \\
\hline
\end{tabular}

2. táblázat: A képzés területeinek aránya a vizsgált tantervekben

Amint a fenti táblázatból is kiderül a jelenleg használt tantervben a pedagógiai-pszi-

10 2007-ig a szak föiskolai szintű oklevelet bocsátott ki a végzős hallgatóknak, 2008-tól viszont már egyetemi oklevelet. A főiskolát végzettek számára két tanévben kiegészítő képzést szervezett az egyetem, mely során egy év alatt egyenértéküsíthették oklevelüket a bolognai rendszerben végzett tanerőkével. Kiegészítő képzést csak két évig szervezett az egyetem, jelenleg a főiskolát végzetteknek is el kell végezniük a három éves képzést az egyetemi oklevél megszerzéséért.

${ }^{11}$ Marosvásárhelyen óvodapedagógusi és tanítói képesítést nyújtott a képzés. chológiai elméleti tárgyak 42,4\%-át töltik ki a képzésnek, ami jelentős növekedés a kezdeti 19,5\%-hoz képest. Ezt a jelentős változást a bolognai rendszerhez való csatlakozás hozta magával, mivel a 2005/2006-ban megírt tanterv első három féléve azonos volt a pedagógia szakon tanuló hallgatókéval, csak a negyedik félévtől váltak szét a csoportok, és az Óvodai és elemi iskolai oktatás pedagógiája szakon tanuló hallgatók az utolsó három félévben a tantárgypedagógiákra és az azokhoz kapcsolódó gyakorlatokra összpontosítottak. 
Így ebben a tantervben az általános műveltségi tantárgyak aránya felére csökken az előző tantervhez képest (16,9\%). Bár a pedagógiai gyakorlatraszántidő folyamatosan növekedett a vizsgált tantervekben, a jelenlegi tantervben visszaesés mutatkozik, a képzési idő 11,32\%át teszi ki. A 2012/2013-as tanterv készítői a gyakorlat megerősítését képviselték, azonban a központi előírások kevés szabadságot biztosítottak számukra ${ }^{12}$. A kezdeti tantervek nyelvoktatást is biztosítottak a hallgatóknak, a képzés negyedét a nyelvi képzés tárgyai képezték. A nyelvoktatói képzés megszűntével növekedett a pedagógiai-pszichológiai elméleti tárgyak, a tantárgypedagógiák és az általános műveltségi tárgyak aránya a képzésben.

Kutatásunk szempontjából fontos ismernünk a fentiekben bemutatott tantervekben a képzési területek arányát, hiszen arra kerestünk választ, hogy a tantervi változások, a képzés megszilárdulása, miként hatott a képzés hallgatók általi megítélésére.

\section{Az óvodapedagógus - és tanítóképzős hallgatók véleménye a képzésről}

2002 és 2015 között többfázisú kutatást végeztünk a BBTE Pszichológia és Neveléstudományok Karán, az óvodapedagógus- és tanítóképző szakon annak érdekében, hogy megtudjuk, miként vélekednek a III. éves hallgatók képzésük színvonaláról, illetve, hogyan ítélik meg saját felkészültségüket a pedagógusi pályára. Vizsgáltuk, milyen tényezők befolyásolják a képzés és a felkészültség megítélését, illetve tudni szerettük volna, hogy igénylik-e a hallgatók a továbbtanulást, a magiszteri fokozat megszerzését.

A vizsgálat időpontjai nem véletlenszerüek, 2002-2003-ban az első két végzős évfolyamot kérdeztük meg, akik kettős (tanító - idegen nyelv oktatói) illetve hármas képesítést

\footnotetext{
12 Az ARACIS (a felsőoktatás minőségellenőrzésével foglalkozó intézmény) konkrétan elöírja a képzésben használt kötelező, opcionális és fakultatív tantárgyak arányát, illetve megszabja az alapozó tárgyak, szaktárgyak és kiegészítő tárgyak listáját, így a képzés tartalma központilag nagymértékben meg van szabva.
}

(óvodapedagógus - tanító - idegen nyelv oktatói) szereztek nappali tagozaton illetve kettős (óvodapedagógus - tanító) képesítést távoktatásos formában; 2010-ben a bolognai rendszerben végzett hallgatókat kérdeztük meg, akik az első egyetemi szintű képzést biztosító tanterv szerint tanultak (képesítésük: tanár az óvodai és elemi iskolai oktatásban) illetve 2015-ben a PADI által kidolgozott tanterv szerint képzett végzős hallgatók véleményére voltunk kíváncsiak.

A kutatást a kolozsvári egyetem minden kihelyezett tagozatán elvégeztük, így egységes képet kaptunk a szak müködéséről: Kézdivásárhelyen, Kolozsváron, Nagyenyeden, Marosvásárhelyen ${ }^{13}$, Szatmárnémetiben és Székelyudvarhelyen (1. 2. ábra)

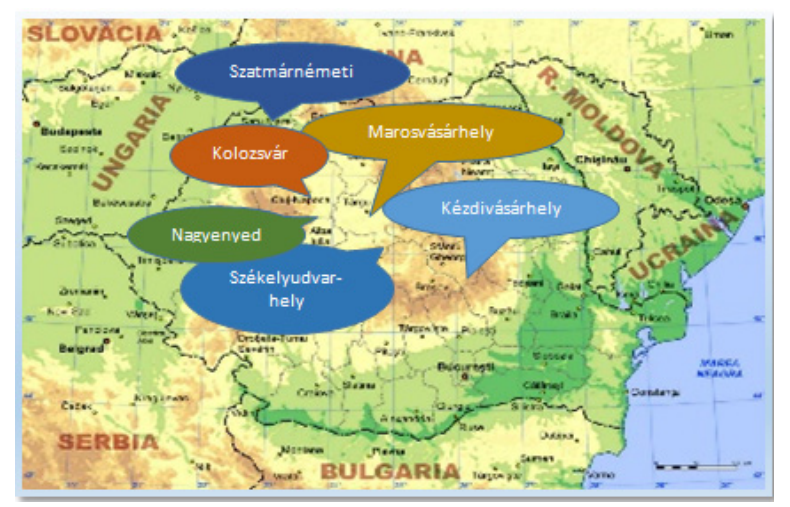

2. ábra: A magyar tannyelvű óvodapedagógus - és tanítóképzés helyszínei a BBTE-n

Teljeskörü mintavételre törekedtünk, az adott évek harmadéves hallgatóinak körében, a kérdőívek kitöltésében az egyes helyszíneken tanító oktatók segítettek. Mivel a minta elég nagyszámú volt (656), az írásbeli kikérdezés módszerét alkalmaztuk, eszköze pedig a kérdőív volt. Az adatok feldolgozásánál leíró matematikai (relatív és abszolút gyakoriság, átlag, szórás) illetve statisztikai módszereket (korrelációszámítás, t-próba) alkalmaztunk az SPSS program segítségével.

\footnotetext{
${ }^{13}$ Nagyenyeden csak 2002-2003-ban végeztük el a kikérdezést, mivel nem sokkal ezután ezt a kihelyezett tagozatot megszűntették, Marosvásárhelyen pedig csak 2010-től kérdeztük meg a hallgatókat.
} 


\section{A minta bemutatása}

A mintában tehát 656 hallgató vett részt a hat helyszínen: Székelyudvarhelyen 257-en, Szatmárnémetiben 165-en, Kézdivásárhelyen 108-an, Kolozsváron 55-en, Marosvásárhelyen 50-en, Nagyenyeden 21-en töltötték ki a kérdőívet. Amint a 3. táblázatból is jól kivehető a hallgatói létszám egyre csökkent az évek folyamán ${ }^{14}$.

$\begin{array}{lcccc} & \mathbf{2 0 0 2 -} & \mathbf{2 0 1 0} & \mathbf{2 0 1 5} & \boldsymbol{\Sigma} \\ & \mathbf{2 0 0 3} & & & \\ \text { Szatmárnémeti } & 108 & 44 & 13 & 165 \\ \text { Székelyudvarhely } & 123 & 87 & 47 & 257 \\ \text { Kézdivásárhely } & 55 & 41 & 12 & 108 \\ \text { Nagyenyed } & 21 & - & - & 21 \\ \text { Marosvásárhely } & - & 26 & 24 & 50 \\ \text { Kolozsvár } & 13 & 22 & 20 & 55 \\ \text { Összesen } & 320 & 220 & 116 & 656\end{array}$

3. táblázat: A minta helység és kitöltés időpontja szerinti megoszlása

A nemek megoszlása tekintetében az arányok megfelelnek az óvodapedagógusi illetve tanítói pályán elhelyezkedők arányának, hiszen a válaszadók 97\%-a nő, s csak 3\%-a férfi. Az életkori megoszlás tekintetében azonban a minta sajátos, hiszen többféle korosztály képviselteti magát: a válaszadók 63,1\%-a 20-25 év közötti, közvetlenül a középiskola befejezése után, vagy pár évvel később jelentkezett a képzésre, 13,4\%-a 26-30 év közötti, 12,7\%-a 31-35 év közötti, illetve a minta 10,8 \%-a 3650 év közötti (1. 3. ábra) ${ }^{15}$.

14 Bár a kérdőív kitöltésében nem vett részt minden harmadéves diák (esetleg éppen hiányoztak), a létszám csökkenés jellemző az óvodapedagógus-, tanítóképző szakon.

15 Az életkor szerinti szórás egyik magyarázata, hogy a képzés törvényi szabályozása az elmúlt húsz évben folyamatosan változott, így tanítóképző líceumot, posztliceális képzést, illetve főiskolát végzett gyakorló pedagógusok is jelentkeztek a képzésre, hogy megszerezhessék a szakterületükön a legmagasabb végzettséget.

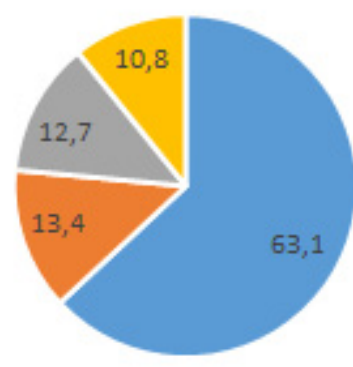

- 20-25 év | 26-30 év | 31-35 év | 36-50 év

3. ábra: A minta életkor szerinti megoszlása

A válaszadók 58,2\%-a nappali, 41,8\%-a távoktatásos képzési formában végezte el a föiskolát, illetve egyetemet. 2002-ben csak nappali képzésben végzett hallgatók voltak a szakon, a többi időpontban változó arányban távoktatásos hallgatók is kitöltötték a kérdőívet. A mintában résztvevő távoktatásos hallgatók 55,1\%-a Székelyudvarhelyen, 27,4\%-a Szatmárnémetiben, 15,7\%-a Kézdivásárhelyen, 1,8\%-a Kolozsváron végezte tanulmányait (1. 4. ábra és táblázat).

$\begin{array}{lcc} & \text { Nappali } & \text { Távoktatás } \\ 2002 & 89 & - \\ 2003 & 103 & 128 \\ 2010 & 105 & 115 \\ 2015 & 85 & 31 \\ \text { Összesen } & 382-58,2 \% & 274-41,8 \%\end{array}$

4. táblázat: A minta képzési forma szerinti megoszlása

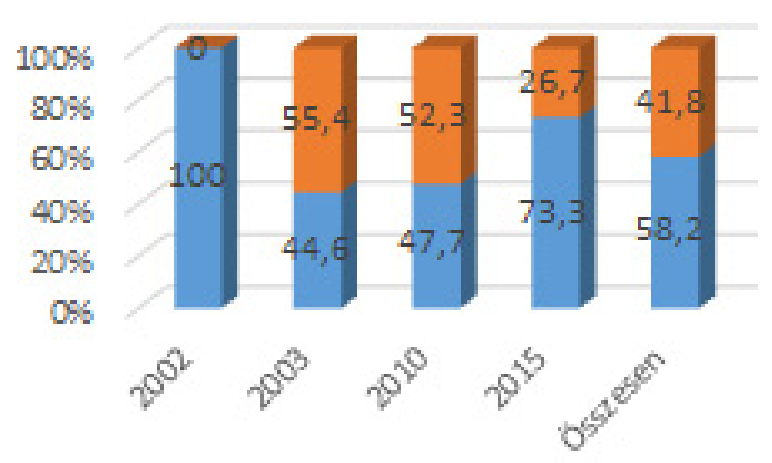

4. ábra: A képzési formák arányai a mintában

A képzésben résztvevő hallgatók különböző előképzettséggel rendelkeznek: többségük, 66,7\% elméleti líceumban végzett, 
25,5\% pedagógiai líceumban szerzett már előzetesen szakképesítést, kisebb arányban vannak azok, akik föiskolai vagy egyetemi oklevéllel rendelkeznek (1. 5. ábra).

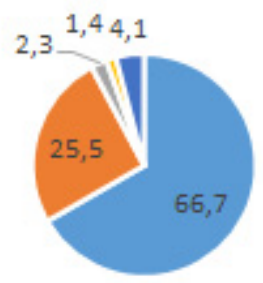

$$
\begin{aligned}
& \text { - érettségi elméleti líceumban } \\
& \text { - érettségi pedagógiai líceumban } \\
& \text { = föiskolai oklevél } \\
& \text { = egyetemi oklevél } \\
& \text { - más }
\end{aligned}
$$

5. ábra: A minta előzetes végzettség szerinti megoszlása

Az adatok elemzése szempontjából jelentős, hogy a megkérdezett hallgatók tanítottak-e a tanulmányi idő alatt. Azt tapasztalhattuk, hogy a hallgatók nagy része hosszabb-rövidebb ideig tanított a képzés során. Leginkább a távoktatásos hallgatókra jellemző ez a tendencia, hiszen a pedagógusi képzettséggel rendelkező hallgatók azért választották ezt a képzési formát, mivel már tanítottak, s csak hétvégén tudtak részt venni a kontakt-órákon (1. 6. ábra, 5. táblázat)

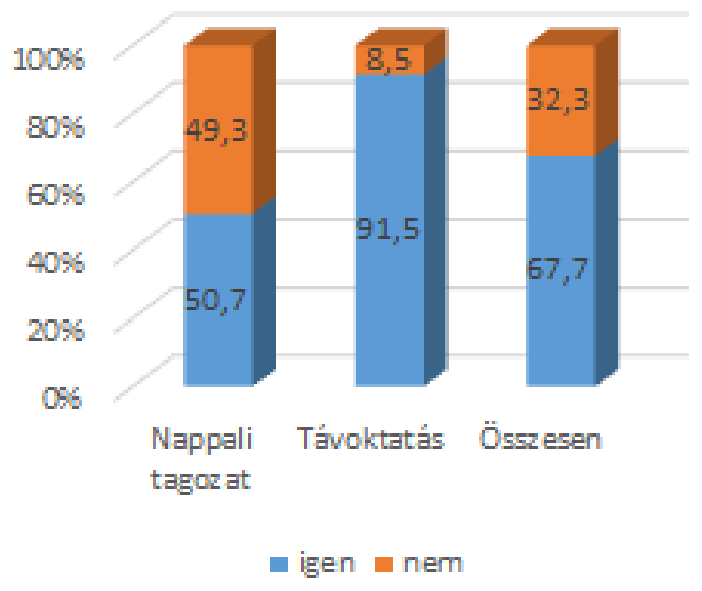

6. ábra: Tanítottak-e a képzés évei alatt?

$\begin{array}{lcc} & \text { IGEN } & \text { NEM } \\ \text { Elméleti líceum } & 55,8 \% & 44,2 \% \\ \text { Pedagógiai líceum } & 92,2 \% & 7,8 \% \\ \text { Főiskola } & 93,3 \% & 6,7 \% \\ \text { Egyetem } & 75 \% & 25 \% \\ \text { Más } & 95,8 \% & 4,2 \% \\ \text { Összesen } & 67,8 \% & 32,2 \%\end{array}$

5. táblázat: Tanítottak-e a képzés évei alatt?

\section{Az adatok bemutatása és értelmezése}

A vizsgálat megkezdése előtt feltételeztük, hogy a képzés megítélését befolyásolja a kérdőív kitöltésének az ideje, vagyis, hogy milyen tanterv szerint folyt a képzés az adott időpontban, hiszen nem mindegy, hogy a képzésre szánt három év alatt milyen képzettséget szerez a hallgató. Ezt a feltevésünket támasztották alá az előző kutatások során nyert adatok is (Szabó-Thalmeiner, 2009, 2011a, 2013). Kérdés volt számunkra az is, hogy a képzés mely oldalával elégedettebbek a hallgatók, az elméleti vagy a gyakorlati képzéssel, hiszen a képzés felsőfokúvá válásával félő volt, hogy a gyakorlati képzés háttérbe szorul, a tanulmányok túl elméleti jellegűvé válhatnak. Azt feltételeztük, hogy a hallgatók az elméleti képzéssel elégedettebbek lesznek, mint a gyakorlati képzéssel.

$\mathrm{Az}$ adatok feldolgozása során azt vehettük észre, hogy a képzés általános megítélése javult 2015-re. Ugyanez a tendencia figyelhető meg a gyakorlati képzés megítélésénél is, viszont az elméleti képzéssel való elégedettség az évek során folyamatosan csökkent, bár 2015-ben még mindig a legnagyobb minősítést kapta. Az elméleti képzés megítélésének csökkenésével párhuzamosan a hallgatók egyre inkább úgy vélték, hogy a képzés nem túl elméletorientált (1. 7. ábra). 
Felsőfokú óvodapedagógus- és tanítóképzés a Babeș-Bolyai Tudományegyetemen

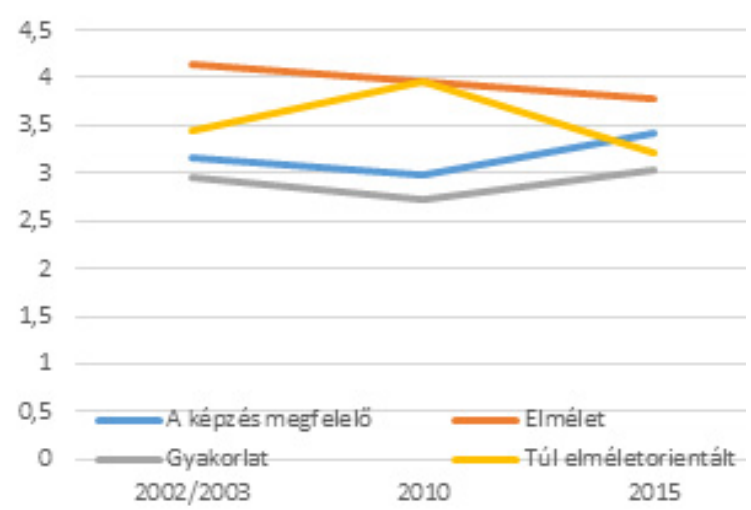

7. ábra: A képzés megítélése

Az átlagértékek ${ }^{16}$ vizsgálata során azt tapasztalhatjuk, hogy a bolognai rendszerü tömbösített tanterv szerint felkészített hallgatók a legkevésbé elégedettek a képzéssel, s azon belül a gyakorlati képzéssel, s bár ők ítélik meg legelméletorientáltabbnak a képzést, az elméleti képzéssel kevésbé elégedettek, mint a 2002-2003-ban végzett társaik (l. 6. táblázat).

$\begin{array}{lccccc} & \text { N } & \begin{array}{c}\text { Általá- } \\ \text { nosan }\end{array} & \begin{array}{c}\text { Elmé- } \\ \text { let }\end{array} & \begin{array}{c}\text { Gyakor- } \\ \text { lat }\end{array} & \begin{array}{c}\text { Elmélet- } \\ \text { orientált }\end{array} \\ 2002- & 307 & 3,15 & 4,13 & 2,95 & 3,44 \\ 2003 & & & & & \\ 2010 & 216 & 2,99 & 3,96 & 2,72 & 3,96 \\ 2015 & 115 & 3,43 & 3,78 & 3,04 & 3,22 \\ \Sigma & 523 & 3,15 & 4,01 & 2,89 & 3,57\end{array}$

6. táblázat: A képzés megítélésének átlagértékei egy ötfokú skálán

Ez az eredmény kissé ellentmond a tantervek elemzésénél tapasztaltaknak, hiszen a 2. táblázatból azt olvashatjuk ki, hogy a pedagógiai gyakorlat aránya ebben a tantervben a legmagasabb (19,5\%). Viszont a tanterv tüzetesebb elemzése során azt vehetjük észre, hogy a gyakorlati órák csak a negyedik félévben jelennek meg, viszonylag magas heti óraszámban. A 2015-ben megkérdezett hall-

\footnotetext{
16 A válaszadóknak 1-5-ig terjedő skálán kellett megjelölniük elfogadásuk mértékét, ahol 1 - az egyáltalán nem tartja megfelelőnek, az 5 pedig a teljes mértékben elégedettet jelentette.
}

gatók viszont elégedettebbek a gyakorlati képzéssel, bár a pedagógiai gyakorlat a tantervük 11,32\%-át teszi ki. Az ő esetükben azonban a gyakorlati képzés már a második félévben megjelenik megfigyelési gyakorlattal, ezért több idő marad a tanítási készségek kialakulására, viszonylagos megszilárdulására.

Az adatok elemzése során felmerült a kérdés, hogy a tantervi változások mellett még milyen tényezők befolyásolják a hallgatókat a képzés megítélésekor. Azt tapasztalhattuk, hogy a távoktatáson végzett hallgatók globálisan és területenként is jobbnak minősítették a képzést, mint nappalis társaik (1. 7. táblázat).

$\begin{array}{lrrrrl}\text { Tagozat } & \text { N } & \begin{array}{c}\text { A kép- } \\ \text { zés }\end{array} & \begin{array}{c}\text { Elmé- } \\ \text { let }\end{array} & \begin{array}{c}\text { Gyakor- } \\ \text { lat }\end{array} & \begin{array}{l}\text { Elmélet- } \\ \text { orientált }\end{array} \\ \text { Nappali } & 374 & 2,93 & 3,84 & 2,59 & 3,54 \\ \text { Távoktatás } & 264 & 3,47 & 4,25 & 3,32 & 3,63 \\ \text { Összesen } & 638 & 3,15 & 4,01 & 2,89 & 3,57\end{array}$

7. táblázat - A képzés megítélése képzési forma függvényében

Ez újból elgondolkodtató adatnak számít, mivel a gyakorlatban azt vehetjük észre, hogy a nappalis hallgatók sokkal több előadáson, szemináriumon vesznek részt, mint távoktatásos társaik, a távoktatáson sokkal nagyobb hangsúly fektetődik az önálló tanulásra, felkészülésre. Ezért tovább vizsgálódtunk és azt tapasztalhattuk, hogy a képzés megítélése erősen korrelál azzal is, hogy a képzés évei alatt a hallgató tanított-e vagy sem (a gyakorló pedagógusok pozitívabbnak minősítették a gyakorlati felkészítést (1. 8. táblázat), illetve, hogy milyen helységben végezte tanulmányait a megkérdezett hallgató.

$\begin{array}{lccccc}\text { Tanított-e } & \text { N } & \begin{array}{c}\text { A kép- } \\ \text { zés }\end{array} & \begin{array}{c}\text { Elmé- } \\ \text { let }\end{array} & \begin{array}{c}\text { Gyakor- } \\ \text { lat }\end{array} & \begin{array}{c}\text { Elmélet- } \\ \text { orientált }\end{array} \\ \text { IGEN } & 425 & 3,21 & 4,07 & 3,08 & 3,57 \\ \text { NEM } & 208 & 3,02 & 3,88 & 2,49 & 3,58 \\ \text { ÖSSZESEN } & 633 & 3,15 & 4,01 & 2,89 & 3,57\end{array}$

8. táblázat - A képzés megítélése annak függvényében, hogy a hallgató tanított-e

A képzés megítélése mellett az is kérdés volt számunkra, hogy mennyire érzik a hallgatók magukat felkészültnek a pedagógusi szakma gyakorlására a három évet követő- 
en ${ }^{17}$. Azt feltételeztük, hogy az előzetes végzettség (pl. hogy valaki pedagógiai líceumot végzett-e vagy sem), illetve, hogy a hallgató a képzéssel párhuzamosan tanított-e gyakorló pedagógusként meghatározza majd a felkészültsége mértékének megítélését18.

$\mathrm{Az}$ adatok elemzése során beigazolódott előzetes feltevésünk, a pedagógiai líceumot, vagy előzetesen föiskolát végzett hallgatók ítélték meg legkedvezőbben felkészültségük mértékét (4,3 illetve 4,21 átlaggal) az elméleti líceumot $(3,81)$, illetve a más egyetemet végzett hallgatókkal $(3,73)$ szemben. Az átlageredményeket tekintve úgy gondolom, hogy elégedettek lehetünk a felkészültségük szintjének általános megítélésével, hiszen az ötfokú skálán a hallgatók szinte 4-es átlagot jelöltek meg $(3,97)$. (l. 8. ábra)

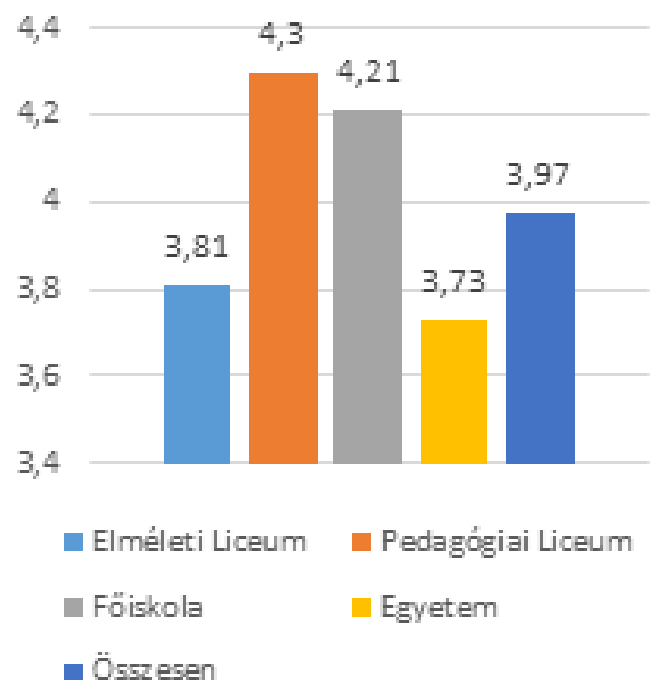

8. ábra: A felkészültség megítélésének átlagértékei előzetes végzettség szerint

Akárcsak a képzés általános és területenkénti megítélésénél, a felkészültség mértéké-

\footnotetext{
17 A felkészültség megítélését nyilván befolyásolja a hallgató igény- és elvárás szintje, önbizalma, önértékelése is, viszont a felkészültség megítélése a képzés minőségétől is nagy mértékben függ. Különösen jó visszacsatolás a képző intézménynek a felkészültség területeinek a megítélése, hiszen ezáltal visszajelzést kap arról is, hogy milyen hiányosságokat kell pótolnia még a képzés során.

18 Ez az előfeltevésünk abból indult ki, hogy a pedagógiai líceumot végzett hallgatók összesen hét (4+3), illetve 8 $(5+3)$ évet készültek a szakma elsajátítására, míg az elméleti líceumot végzett hallgatók csak hármat.
}

nek megbecsült értékét befolyásolta a képzés helyszíne (a legelégedettebbek a kézdivásárhelyi $(4,04)$, székelyudvarhelyi $(4,03)$ és szatmárnémeti (4) hallgatók), a képzés formája (a távoktatásos hallgatók felkészültebbnek ítélték meg magukat), illetve az, hogy a képzés évei alatt tanított-e a hallgató.

A képzés tartalmának javítása érdekében azonban nagyon tanulságos megfigyelnünk, hogy a hallgatók, mely területeken érzik magukat felkészültebbeknek és hol éreznek hiányosságokat.

Az átlagértékeket rangsorba helyezve a 9. táblázatban található sorrendet kapjuk.

\begin{tabular}{|c|c|}
\hline Felkészültségi terület & Átlagérték \\
\hline Tanítási eszközök elkészítése & 4,40 \\
\hline Lecketervek megírása & 4,37 \\
\hline $\begin{array}{l}\text { Diákok munkájának folyamatos } \\
\text { ellenőrzése és értékelése }\end{array}$ & 4,27 \\
\hline $\begin{array}{l}\text { Tanulók aktivitásának biztosítása a } \\
\text { tanórán }\end{array}$ & 4,20 \\
\hline Változatos módszerek alkalmazása & 4,19 \\
\hline Szülőkkel való kapcsolattartás & 4,12 \\
\hline Kirándulás megszervezése & 4,11 \\
\hline Diákok tudásszintjének minősítése & 4,07 \\
\hline Órarend elkészítése & 4,00 \\
\hline Diákok közötti konfliktusok kezelése & 3,97 \\
\hline $\begin{array}{l}\text { Tanító-diák kapcsolatban jelentkező } \\
\text { konfliktus kezelése }\end{array}$ & 3,92 \\
\hline $\begin{array}{l}\text { Differenciálás biztosítása az } \\
\text { osztályteremben }\end{array}$ & 3,86 \\
\hline Szülői értekezlet megtartása & 3,85 \\
\hline $\begin{array}{l}\text { A pedagógusi munka folyamatos } \\
\text { értékelése }\end{array}$ & 3,6 \\
\hline Tematikus terv összeállítása & 3,5 \\
\hline Éves munkaterv összeállitása & 3,48 \\
\hline Szakköri tevékenység megszervezése & 3,35 \\
\hline
\end{tabular}

9. táblázat: A felkészültségi területek átlagértékei 
Felsőfokú óvodapedagógus- és tanítóképzés a Babeș-Bolyai Tudományegyetemen

Azt tapasztalhattuk, hogy a tervezésben való jártasságuk inkább az órai tervezésre korlátozódik, kevésbé gyakorlottak a hosszú távú tervezésben, az éves és tematikus terv elkészítésében, az órarend összeállításában (ennek a területnek a fejlesztésére külön is felhívták a figyelmet a kérdőívet záró nyitott kérdésre adott válaszukban). Felkészültek a változatos oktatási módszerek alkalmazásában, a tanulók tanórai aktivizálásában, a tanítási eszközök elkészítésében, feladatlapok összeállításában, viszont kevésbé tudnak differenciált munkát illetve csoportmunkát szervezni. A szülőkkel való kapcsolattartásra is felkészültek, bár igényelnék a szülői értekezlet megtervezésére, lebonyolítására vonatkozó ismeretek bővebb elsajátítását. Úgy érzik, hogy kirándulást is tudnak szervezni, de a szakköri tevékenység megszervezésekor már nehézségbe ütköznének. Erősségük a diákok minősítése, értékelése is, de kevésbé érzik magukat felkészülve a saját, pedagógusi munkájuk folyamatos értékelésére, illetve a konfliktusok kezelésére.

A felsorolt területek kitöltési idő szerinti vizsgálatakor azt vehettük észre, hogy 2015-re javult a hallgatók felkészültségének a megítélése az előző évekhez képest a szakkör megszervezésének, a tematikus tervezés elkészítésének, a tanulók aktivizálásának és a változatos módszerek alkalmazásának terén.

Kutatásaink során megkértük a hallgatókat, hogy egy adott tantárgylistából válasszák ki azokat a tantárgyakat, amit szívesen tanulná- nak (tanultak volna) a képzés során. Az összesített eredményekből kiderül, hogy a hallgatók igényelnék a gyakorlati, képességfejlesztő tantárgyak jelenlétét a tantervben: kommunikációs képességek és önismeret fejlesztése, drámapedagógia, feszültségkezelés, a tanulók megismerésének módszerei, tehetséggondozás. Kevésbé érdeklődtek az iskolavezetéstan, a felnőttoktatás, iskolai mentálhigiéné iránt. A tantervek újraírásakor az opcionális tantárgyak listájának összeállításakor figyelembe vettük a hallgatók véleményét is, a 2015-ben végzettek már választhatták az önismeret fejlesztését, a konfliktuskezelés tantárgyat, illetve a drámapedagógia már a 2010-ben végzett hallgatók számára is opcionális tantárgy volt.

A kutatás során bebizonyosodott, hogy a felkészültség mértékének megítélése szignifikánsan korrelál $(\mathrm{p}<0,01)$ a képzés általános, elméleti és gyakorlati oldalának megítélésével, tehát joggal mondhatjuk, hogy a képzés minőségétől függ, hogy a hallgató mennyire érzi magát felkészültnek a szakma gyakorlására.

Kutatásunk során arra kerestünk még választ, hogy a hallgatók szeretnének-e az Intézet keretén belül továbbtanulni, magiszteri fokozatot szerezni, és mi motiválja őket erre a lépésre.

Amint a 10. táblázatból is jól látható, a végzős hallgatók 79\%-a gondolkodik a továbbtanuláson, a válaszadók fele pedig határozottan állítja, hogy szeretne továbbtanulni, magiszteri fokozatot szerezni.

$\begin{array}{lcccc} & \text { Igen } & \text { Nem } & \text { Talán } & \text { Nem tudom } \\ \text { Kézdiv. } & 50 \% & 15,4 \% & 26,9 \% & 7,7 \% \\ \text { Kolozsvár } & 64,3 \% & 7,1 \% & 23,8 \% & 4,8 \% \\ \text { Marosv. } & 54 \% & 14 \% & 24 \% & 8 \% \\ \text { Szatmár } & 38,6 \% & 24,6 \% & 31,6 \% & 5,3 \% \\ \text { Udvarhely } & 57,7 \% & 11,9 \% & 26,1 \% & 4,5 \% \\ \text { Összesen } & 53,4 \% & 14,3 \% & 26,6 \% & 5,7 \%\end{array}$

10. táblázat: A hallgatók továbbtanulás iránti igénye

A gyakorlat azonban azt mutatja, hogy a kolozsvári tagozaton müködő magiszteri képzésen ennél sokkal kevesebb hallgató tanult tovább. Ennek okát keresve rákérdeztünk, hogy a hallgatók hol szeretnék elvégezni a két éves szakképesítést. Azt tapasztalhattuk, hogy a vidéki tagozaton tanulók az eddigi képzésük helyszínén jelentkeznének magiszteri képzésre, s mindaddig, amíg ez nem valósulhat meg, elodázzák a továbbképzésüket (1. 9. ábra).

A 2010 és 2015-ös adatokat összehasonlítva azt tapasztalhattuk, hogy a magiszteri képzésben való részvételi kedvet befolyásolta az is, 
hogy a képzés helyszínén kilátásban volt-e magiszteri képzés beindítása ${ }^{19}$. A hallgatók helyzetét ismerve a helyszínhez való ragaszkodás érthetö, hiszen az egyetem befejezése után a hallgatók többsége munkába áll, így egyfelől nehezebben tudja bevállalni a folyamatos utazást Kolozsvárra, másfelől pedig a költségek is sokkal nagyobbak, ha a kolozsvári központban kell a tanulmányaikat elvégezniük.

\section{Hol tanulna tovább?}

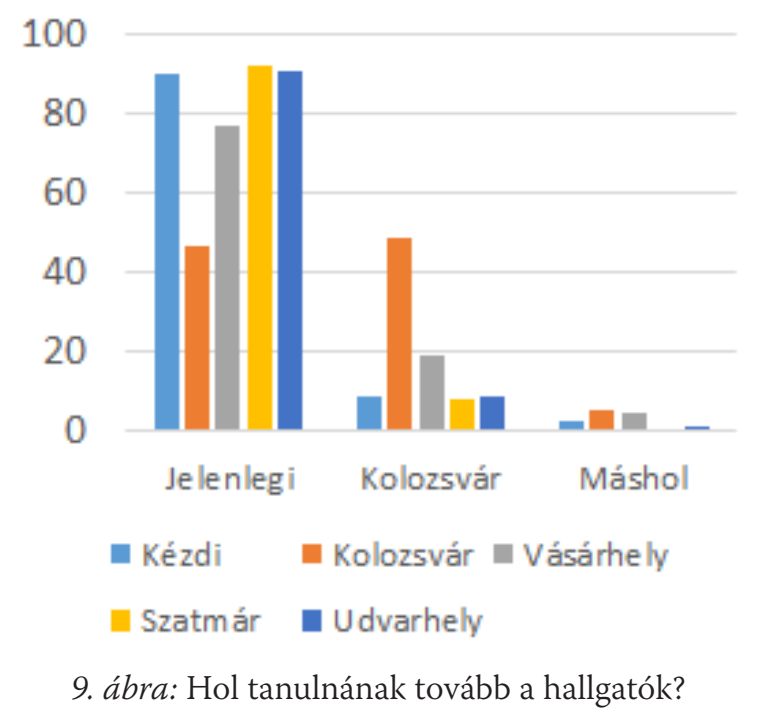

Amint az előbbi elemzésből kiderült, dacára annak, hogy a BA szintű képzés elegendő az óvodapedagógusi, illetve tanítói állás betöltéséhez, mégis sok hallgató szívesen továbbtanulna és MA szintű végzettséget szerezne. Utánajártunk, mi motiválja a hallgatókat a továbbtanulásra, és azt tapasztalhattuk, hogy legtöbbjüket $(77,2 \%)$ a tudásvágy, a szakmai ismeretek gyarapítása sarkallja a továbbtanulásra, illetve a magasabb végzettség megszerzése (59,3\%). A továbbtanulni szándékozók csupán egy harmada a magasabb fizetés (32,5\%), illetve a jobb elhelyezkedés és magasabb pontszám reményében végezné el a magiszteri képzést. A válaszadók kisebb arányban a kollégákkal való kapcsolattartást jelölték meg motiváló tényezőként (11,4\%).

\footnotetext{
19 A szatmárnémeti és kézdivásárhelyi hallgatók aránya csökkent, a székelyudvarhelyieké megmaradt, a kolozsváriaké megnőtt. Marosvásárhelyen a hallgatók nagy része más egyetem magiszteri képzésére szeretne jelentkezni.
}

\section{Következtetés, összegzés}

Az adatok elemzése alapján megállapíthatjuk, hogy a BBTE Óvoda és elemi iskolai oktatás pedagógiája szakán végzett hallgatók egyre pozitívabban ítélik meg a képzés minőségét, s bár az elméleti képzéssel a legelégedettebbek, a gyakorlati képzés megítélése is egyre kedvezőbb. Valószínű, hogy a tantervek változása, illetve a képzés terén nyert tapasztalat jó hatással volt a képzés minőségének javulására, hiszen a hallgatók a felkészültségüket 2015-re jobbnak ítélték. A különböző időpontokban történt felmérés eredményeit összehasonlítva arra a következtetésre jutottunk, hogy az először bevezetett bolognai tanterv alkalmazása során volt a legkedvezőtlenebb a képzés minőségének, illetve a felkészültség mértékének a megítélése. Bebizonyosodott az az előfeltevésünk is, hogy az előzetesen pedagógiai végzettséget szerzett diákok, illetve azok, akik a képzés évei alatt gyakorlatban is alkalmazhatták a tanultakat felkészültebbnek érezték magukat a szakma gyakorlására. Megállapíthatjuk tehát, hogy a minél több gyakorlati tapasztalat, a sok tanítási gyakorlat megerősíti a képzés hatékonyságát az Óvodai és elemi iskolai oktatás pedagógiája szakon.

A tanítási tartalom szempontjából vizsgálatunk tükröt mutatott arról, hogy mely területeken érzik magukat magabiztosabbnak a hallgatók, illetve, hol éreznek még hiányosságokat. A képzés nagy hangsúlyt fektet a tanóra megtervezésére, megszervezésére és kivitelezésére vonatkozó ismeretek és jártasságok fejlesztésére, viszont háttérbe szorulnak az oktató-nevelő munka más területei, mely a hosszútávú tervezésre, a konfliktusok kezelésére, a szülőkkel való kapcsolattartásra vonatkoznak. A pedagógiai gyakorlat megszervezése során valóban, inkább a tanórai tervezésre van lehetőség, a tanítási-tanulási folyamat megtervezése és kivitelezésére fektetjük a hangsúlyt. A hiányosságok pótlására javasolható a megfigyelési gyakorlat különböző szempontokra történő irányítása, illetve a szemináriumi tevékenységek ezirányú megszervezése: pl. szerepjátékok, gyakorlatok, esettanulmányok, stb. révén. A hallgatók 
Felsőfokú óvodapedagógus- és tanítóképzés a Babeș-Bolyai Tudományegyetemen

igénylik a gyakorlati képzés további erősítését, színesebb tételét ${ }^{20}$.

A hallgatók szeretnének továbbtanulni, magiszteri oklevelet szerezni, s ennek fő célja az új szakmai ismeretek elsajátítása lenne elsősorban. Azonban a magiszteri képzés helyszíneként azt a tagozatot jelölik meg, ahol az alapképzést is végezték. Ebből a válaszból kiindulva érdemes lenne minőségi magiszteri képzést indítani a kihelyezett tagozatokon is a kolozsvári központ mellett.

$\mathrm{Az}$ adatok elemzése során eltérések mutatkoztak tagozatonként, megfigyelhető, hogy bár azonos tantervvel müködnek, a kihelyezett tagozatok helyi sajátosságokkal rendelkeznek. A továbbiakban javasolható a kutatási adatok tagozatonkénti elemzése, és a megfelelő következtetések megfogalmazása a helyi képzés hatékonyságának növelése érdekében.

\section{Szakirodalom}

**:* A Bolognai Nyilatkozat szövege. Az európai felsőoktatási térség. Európa oktatási minisztereinek közös nyilatkozata.1999.

URL: http://www.felvi.hu/felsooktatasimuhely/ archivum/bologna/a_bolognai_nyilatkozat_ szovege/ (2015.11.30)

*:*:egea învățământului nr. 84/1995. In. Monitorul Oficial al României, 1996.I.1. - a 84/1995-ös Oktatási Törvény, In. Románia

\footnotetext{
20 pl. gyakorlatot az összevont osztályokban, vidéki környezetben stb.
}

Hivatalos Közlönye. 1996.I.1. http://legislatie. resurse-pentru-democratie.org/84_1995.php (2012.12.10)

**: Legea educației naționale 1/2011, in. Monitorul Oficial al României anul 179 (XXIII), nr. 18., luni 10 ianuarie 2011. Törvény a nemzeti nevelésről, in. Románia Hivatalos Közlönye, 179. Évf. (XXIII), 18. Sz., hétfő, 2011. Január 10.

Stark Gabriella (2012): Kisebbségi pedagógusképzés Romániában. Esettanulmány a BabesBolyai Tudományegyetem Pedagógia és Alkalmazott Didaktika Intézetéről. In. Educatio 2012/1 p. 133-139. http://www.hier.iif.hu/hu/ educatio_reszletes.php?id=89 (2013.09.27.)

Szabó-Thalmeiner Noémi (2009): Metszet. Az erdélyi magyar állami óvó- és tanitóképzés húsz éve egy vizsgálat tükrében. Státus Kiadó, Csíkszereda.

Szabó-Thalmeiner Noémi (2011a): A bolognai képzés bevezetésének hatása az óvó-, tanítóképzésre a Babes-Bolyai Tudományegyetemen a hallgatók szemszögéből. In. Demény Piroska - Fóris-Ferenczi Rita (szerk.). Új utak és módok az oktatásban. Galaxia Gutenberg, Targu Lapus, p. 52-59.

Szabó-Thalmeiner Noémi (2011b): Az erdélyi magyar pedagógusképzés összehasonlító vizsgálata (1990-2006). In. Keszeg Vilmos (szerk.) Iskolák, iskolamesterek, diákok Erdélyben. Iskola- és oktatástörténeti tanulmányok. Erdélyi Múzeum Egyesület, Kolozsvár. P. 214-223.

Szabó-Thalmeiner Noémi (2013): Állami magyar tannyelvű óvó- és tanítóképzés a BabeșBolyai Tudományegyetemen (1999-2013). In. Kotschy Beáta (szerk): Új utak a pedagóguskutatásban. Líceum Kiadó, Eger. (237-256) 


\section{Primary and pre-school education on the Babeș-Bolyai University}

The following paper presents the findings of a multiphase research that has been conducted among the students at the Kindergarten Teacher Training and Primary School Teacher Training Departments of the Faculty of Psychology and Educational Sciences of the BabesBolyai University. With the aim of providing the right frame for a correct interpretation of the findings, the first part of the paper focuses on the legal background that has been regulating the state tertiary education in Hungarian for kindergarten and primary school teachers over the last sixteen years, as well as the effects on the curriculum of the changes that have occurred. In our survey we tried to find out the opinion of the students in their final year about the quality of the educational process, as well as the level of preparation they achieve for a career in teaching.

Keywords: kindergarten teacher training, primary school teacher training, education in Hungarian outside Hungary, tertiary education

Szabó Thalmeiner Noémi (2017): Felsőfokú óvodapedagógus- és tanítóképzés a Babeș-Bolyai Tudományegyetemen. Gyermeknevelés, 5. 3. sz., 65-76. 